\title{
A new Stenothoe species (Crustacea: Amphipoda: Stenothoidae) living on Boloceropsis platei (Anthozoa: Actiniaria) from Chilean Patagonia
}

\author{
T. Krapp-Schickel ${ }^{1} \cdot$ V. Häussermann ${ }^{2} \cdot$ W. Vader $^{3}$
}

Received: 1 December 2014/Revised: 9 March 2015/Accepted: 18 March 2015/Published online: 1 April 2015

(C) Springer-Verlag Berlin Heidelberg and AWI 2015

\begin{abstract}
This paper describes a new species of Stenothoe (Amphipoda, Stenothoidae), S. boloceropsis sp. nov., collected among the tentacles of the sea anemone Boloceropsis platei Mc Murrich, 1904, found on sublittoral sand of Quellon, Chiloe Island, Chile.
\end{abstract}

Keywords New Stenothoe species - Sea anemone Boloceropsis platei Mc Murrich, 1904 · Northern Patagonian Zone - Chile $\cdot$ Shallow water

$\begin{array}{ll}\text { Abbreviations } \\ \text { A1, } 2 & \text { Antennae } 1,2 \\ \text { art } & \text { Article } \\ \text { Cx } & \text { Coxa }\end{array}$

Communicated by H.-D. Franke.

In this paper, the following terms are applied (see also KrappSchickel 2011: 1-2): tooth: non-articulated pointed ectodermal structure; spine: stout, articulated structure (synonymous with "robust seta"); seta: slender, flexible articulated structure. VH: Vreni Häussermann; GF: Günter Försterra.

\footnotetext{
T. Krapp-Schickel

traudl.krapp@uni-bonn.de

V. Häussermann

v.haussermann@gmail.com

W. Vader

wim.vader@uit.no

1 Zoologisches Forschungsmuseum Alexander Koenig, Adenauerallee 160, 53113 Bonn, Germany

2 Facultad de Recursos Naturales, Escuela de Ciencias del Mar, Universidad Católica de Valparaíso, Avda. Brasil 2950, Valparaíso, Chile

3 Troms $\varnothing$ Museum, University of Tromsø, 9037 Tromsø, Norway
}

$\begin{array}{ll}\text { Ep 1-3 } & \text { Epimeral plates 1-3 } \\ \text { Gn 1,2 } & \text { Gnathopods 1, 2 } \\ \text { Md } & \text { Mandible } \\ \text { Mx 1, 2 } & \text { Maxillae 1, 2 } \\ \text { Mxp } & \text { Maxilliped } \\ \text { P 3-7 } & \text { Peraeopods 3-7 } \\ \text { T } & \text { Telson } \\ \text { U 1-3 } & \text { Uropods 1-3 }\end{array}$

\section{Introduction}

Associations between amphipods and sea anemones are probably not all that rare, but few have been recorded previously. In Chile, they have earlier been described from the widely distributed sea anemone Antholoba achates (Krapp-Schickel and Vader 2009) which is also known for its associations with other crustaceans and molluscs (Häussermann and Försterra 2009). Specimens of a small amphipod species have been observed by Häussermann and Försterra on the two very similar species Boloceropsis platei Mc Murrich, 1904 and Bolocera occidua McMurrich, 1893 between Renihue Fjord $\left(\sim 43^{\circ} \mathrm{S}\right)$ and Madre de Dios Archipielago $\left(\sim 50^{\circ} \mathrm{S}\right)$. Anemones were collected by hand while scuba diving, scratching the pedal disc carefully off the substratum with the finger nail. The present specimens have been collected from a specimen of Boloceropsis platei from Quellon, Chiloe Island, in 1998. The specimens turned out to belong to a new species of Stenothoe (Amphipoda: Stenothoidae), a genus hitherto known mainly from boreal to temperate waters all over the world. The new species is described here. 


\section{Materials and methods}

Between 1998 and early 2014, VH and GF observed, collected, examined and preserved nearly 2,000 specimens of shallow water (to $40 \mathrm{~m}$ depth) sea anemones at nearly 300 sites along the Chilean coast from Arica $\left(\sim 15^{\circ} \mathrm{S}\right)$ to Navarino Island, and the Beagle Channel $\left(55^{\circ} \mathrm{S}\right)$. At 54 of these sites in Chilean Patagonia, they found sea anemones of the species Boloceropsis platei/ Bolocera sp. They collected six specimens of a small amphipod which were living between the tentacles of Boloceropsis platei; they also documented amphipods at 16 additional sites from B. platei and Bolocera occidua (Fig. 1). The amphipods were fixed in $10 \%$ formalin and later preserved in $70 \%$ ethanol. Slides were prepared under a Reichert dissecting microscope with glycerine and/or Faure's medium. Pencil drawings were done using a Wild M5 microscope with camera lucida; the transfer or "inking" was done using the program Adobe Illustrator. The studied amphipod material is deposited at the Crustacean Collection of the Museo de Zoología de la Universidad de Concepción (MZUC-UCCC), Chile, and the Museum of Verona (Italy, MVRCr).

\section{Systematics}

Family Stenothoidae Boeck, 1871

Stenothoe boloceropsis sp. nov. Figures 1, 2, 3, 4 and 5.

Holotype ov. Female $2.5 \mathrm{~mm}$; among the tentacles of the sea anemone Boloceropsis platei Mc Murrich, 1904 collected from sandy bottom at Quellon, Chiloe Island, Chile $\left(43^{\circ} 10^{\prime} \mathrm{S} ; 73^{\circ} 29^{\prime} \mathrm{W}\right), 23 \mathrm{~m}$ depth, 7.2.-8.2. 1998; VH and GF coll.; slide deposited at the Museo civ. Storia nat., Verona (Italy): MVRCr 7719.

Additional material Female $2 \mathrm{~mm}$, same locality, slide inv. nr. MZUC-UCCC 43682.4 spec. 2-2.5 mm in alcohol, stored at the Verona Museum.

Diagnosis Antennae reaching one-third of body length. Gn 1 propodus slender, without palmar corner, $1: \mathrm{w}=3$; Gn 2 propodus somewhat longer than Gn 1 propodus, but twice as wide, hind margin rounded, palm defined by strong spines. P 6, 7 basis oval, regularly rounded, posterior margin not much widened. Telson spinose.

\section{Description}

\section{Bodylength $\quad 2-2.5 \mathrm{~mm}$}

Head Eyes round. Antennae subequal, A1 peduncle art $1=\operatorname{art} 2+$ art 3. Mouthparts: Mx 1 palp with 2 arts, inner plate small; Mx 2 plates in tandem position, inner plate much shorter than outer one. Md body long and slender, molar absent.

Peraeon Cx 1 rectangular; basis anteriorly beset with several long spines; merus not reaching end of triangular carpus, both posteriorly with many spines; propodus slender, narrow, $1: \mathrm{w}=3$, without defined palm, on anterior and posterior margin spines.

Cx 2 oval, three times as long as Cx 1. Gn 2 basis with spines on anterior margin; merus not reaching end of triangular carpus, both arts with spines on posterior margin; propodus twice as wide but scarcely longer than Gn 1 propodus, regularly rounded, palm defined by a group of strong spines. Peraeopods: Cx 3 rectangular; P 3 much smaller than $\mathrm{P} 4$; merus $\mathrm{P} 3$ somewhat thicker than propodus and carpus and anteriorly somewhat lengthened; basis on anterior margin spinose. $\mathrm{Cx} 4$ triangular, longer than $\mathrm{Cx} 3$ and about double width; P 4 basis and merus about same width, merus longer than P 3 merus. Dactyli P 3, P 4 reaching about half length of propodus. P 5 very similar P 3. P 6, 7 similar to each other; basis hind margin regularly rounded, posterodistal corner lengthened; merus scarcely widened, but clearly posterodistally acutely lengthened, reaching half length of carpus.

Pleon Ep 1 posteriorly acutely ending; Ep 2, 3 posteriorly with corner of about $120^{\circ}$; all margins smooth. U 1 spinose peduncle longer than subequal rami; U 2 rami clearly different in length; $U 3$ peduncle $<$ ramus, ramus art 1 subequal art 2, beset with spines. Telson triangular, laminar, with spines. No sexual dimorphism known as yet.

Etymology After the sea anemone Boloceropsis platei Mc Murrich, 1904, on which this species is living. Used as noun in apposition.

Discussion From the Pacific Ocean, only six Stenothoe species are known: S. estacola Barnard, 1962, S. frecanda Barnard, 1962, S. garpoorea Krapp-Schickel, 2009, S. haleloke Barnard, 1970 (syn. S. qingtaoensis Ren, 1992), S. kaia Myers, 1985 and S. verrucosa Krapp-Schickel, 2009. The species $S$. frecanda, S. kaia and $S$. verrucosa show an enlarged rectangular Gn 2 propodus in male (propodus 1:w = about 3); in the male Gn 2 propodus of $S$. estacula and $S$. garpoorea, there is a well-defined palmar corner of about $90^{\circ}$, and Gn 1 propodus is about twice as long as wide. The material of S. qingtaoensis Ren, 1992 from Jiaozhou Bay in East China (12 females, 3 males, length up to $3 \mathrm{~mm}$ ) is most probably a synonym of the single female of $2 \mathrm{~mm}$ of $S$. haleloke Barnard, 1970 from Hawaii and is morphologically very similar to the present new species. It lacks also sexual dimorphism, the antennae are subequal and about one-third length of the body, the eyes are well developed and round, Gn 2 propodus is widened and the 

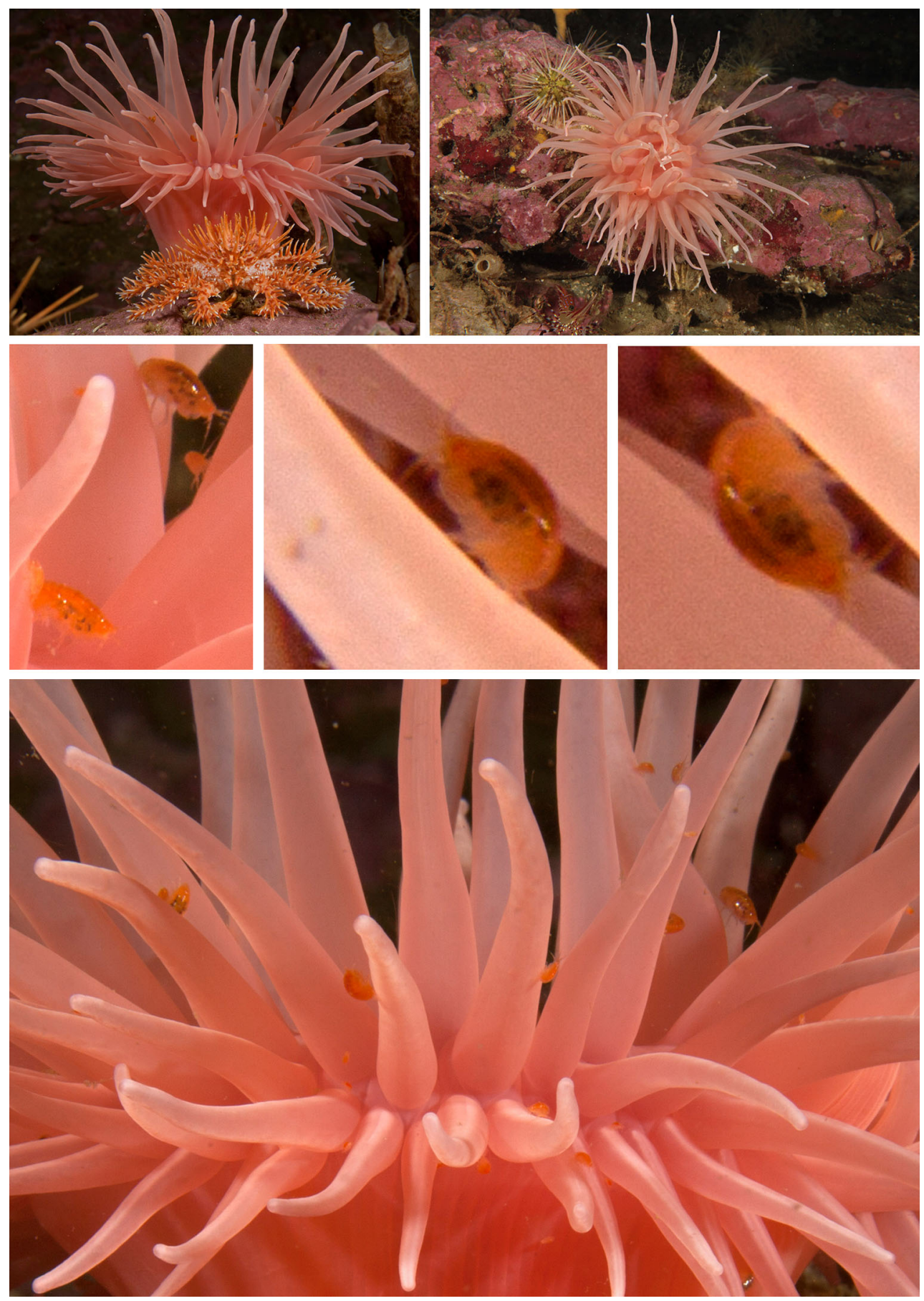

Fig. 1 Boloceropsis platei with associated stenothoid. Source (CVreni Häussermann, all rights reserved

hind margin rounded, and bases of $\mathrm{P} 6,7$ are widened but posteriorly not much rounded. But the differences are Gn 1 propodus similar in shape to Gn 2 propodus with welldefined palmar corner in S. haleloke versus dissimilar, much narrower and lacking palmar corner in the present species; Gn 2 carpus and merus distoposteriorly acutely ending, versus with round corners especially in carpus of the new species; U 2 rami subequal versus clearly unequal in the present species. S. haleloke is reported from littoral algae and not in association with other animals.

It could well be that this species lives in similar conditions as Stenothoe brevicornis G.O.Sars, 1883, which is well known from the Atlantic as obligate associate of the sea anemone Actinostola callosa Verrill, 1882 (Vader and Krapp-Schickel, 1996). Also no sexual dimorphism is 
Fig. 2 Stenothoe boloceropsis n.sp.: A1, $2=$ antenna 1,$2 ; \mathrm{Mx}$ $1,2=$ maxilla 1,2

$\mathrm{Md}=$ mandible;

Mxp = maxilliped
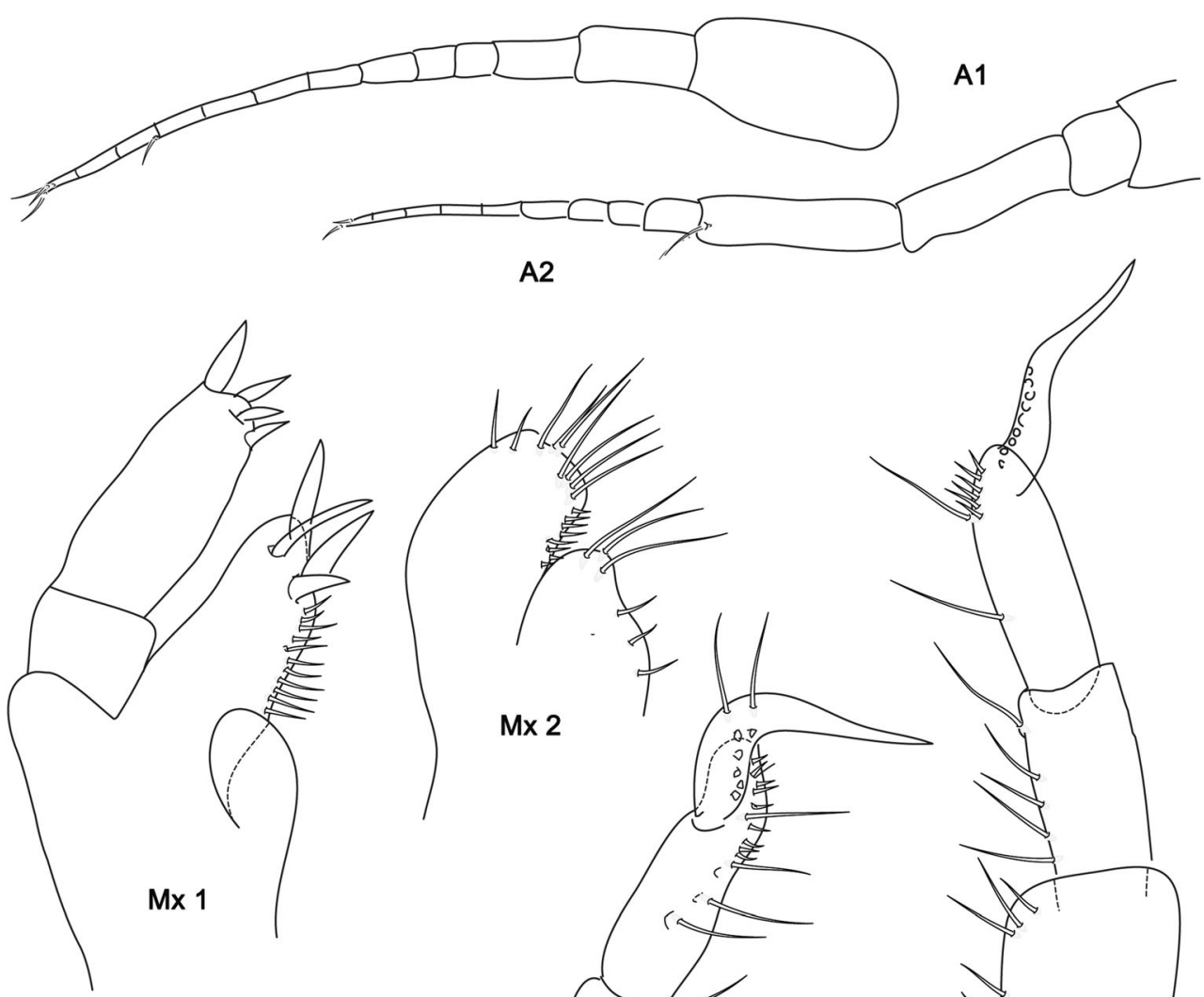

A2
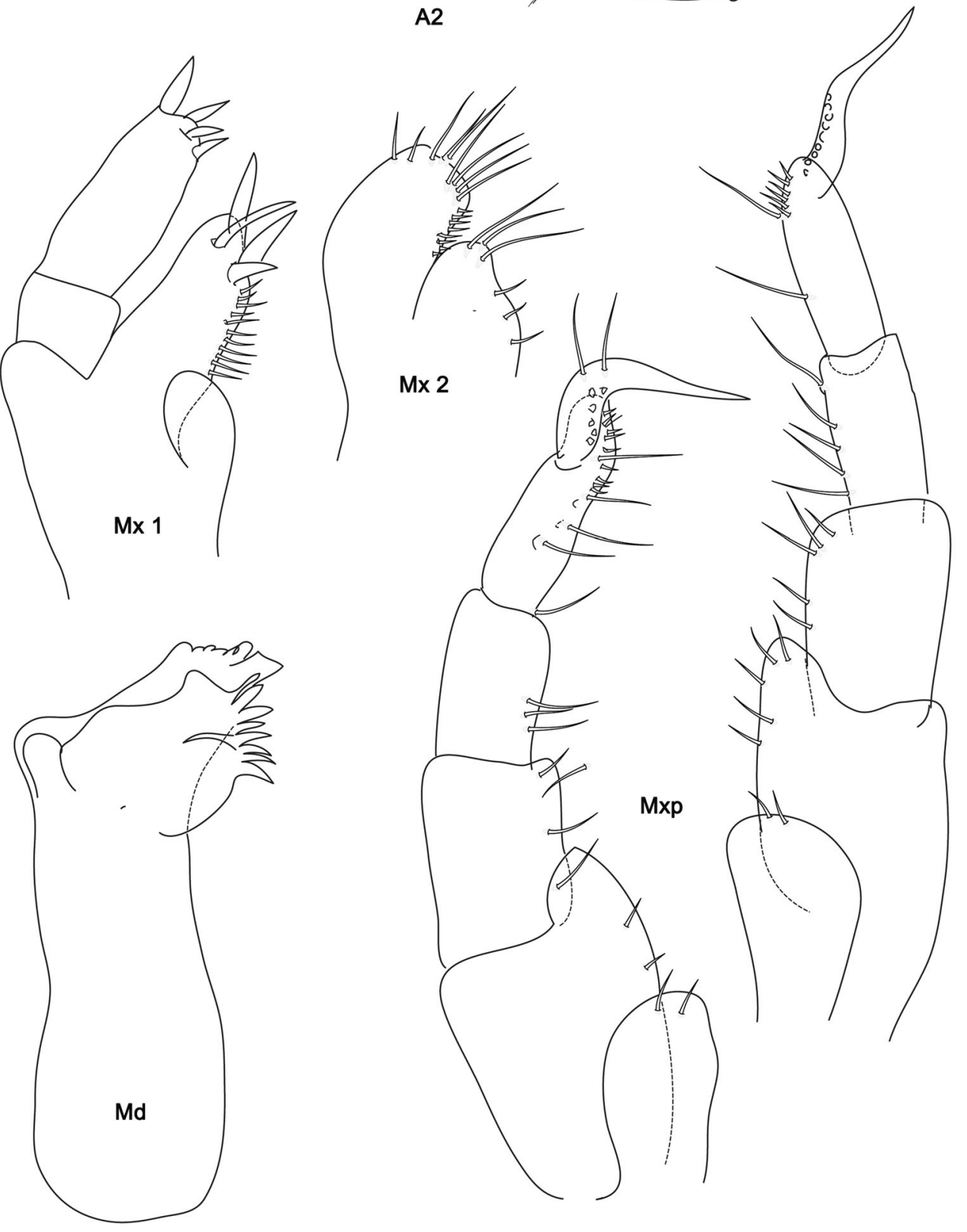

observed, the antennae are subequal in length and about one-third of the body length, the eyes are well developed and round, also $\mathrm{P}$ 6, 7 bases are similarly moderately widened with not much rounded hind margins. But in $S$. brevicornis, the telson is naked, U 3 peduncle is longer than ramus and again $\mathrm{U} 2$ has subequal rami, vs. a spinose telson, U 3 peduncle shorter than ramus and U 2 rami dissimilar in the present species. Among the at present 53 known Stenothoe species, the majority has a Gn 1 propodus about twice as long as wide, and many of them show a clear palmar corner. Only the following species have a $\mathrm{Gn}$ 1 propodus longer than twice the width: $S$. divae BellanSantini, 2005 from the Mid-Atlantic Ridge in about $800 \mathrm{~m}$ depth, S. coutieri Chevreux, 1935 from bathyal of the Açores, S. eduardi Krapp-Schickel, 1976 from the Mediterranean, S. sivertseni Stephensen, 1949 from Tristan 
Fig. 3 Stenothoe boloceropsis n.sp.: Gn 1, 2 resp. Gn 1', $2^{\prime}=$ gnathopods 1,2 in same enlargement
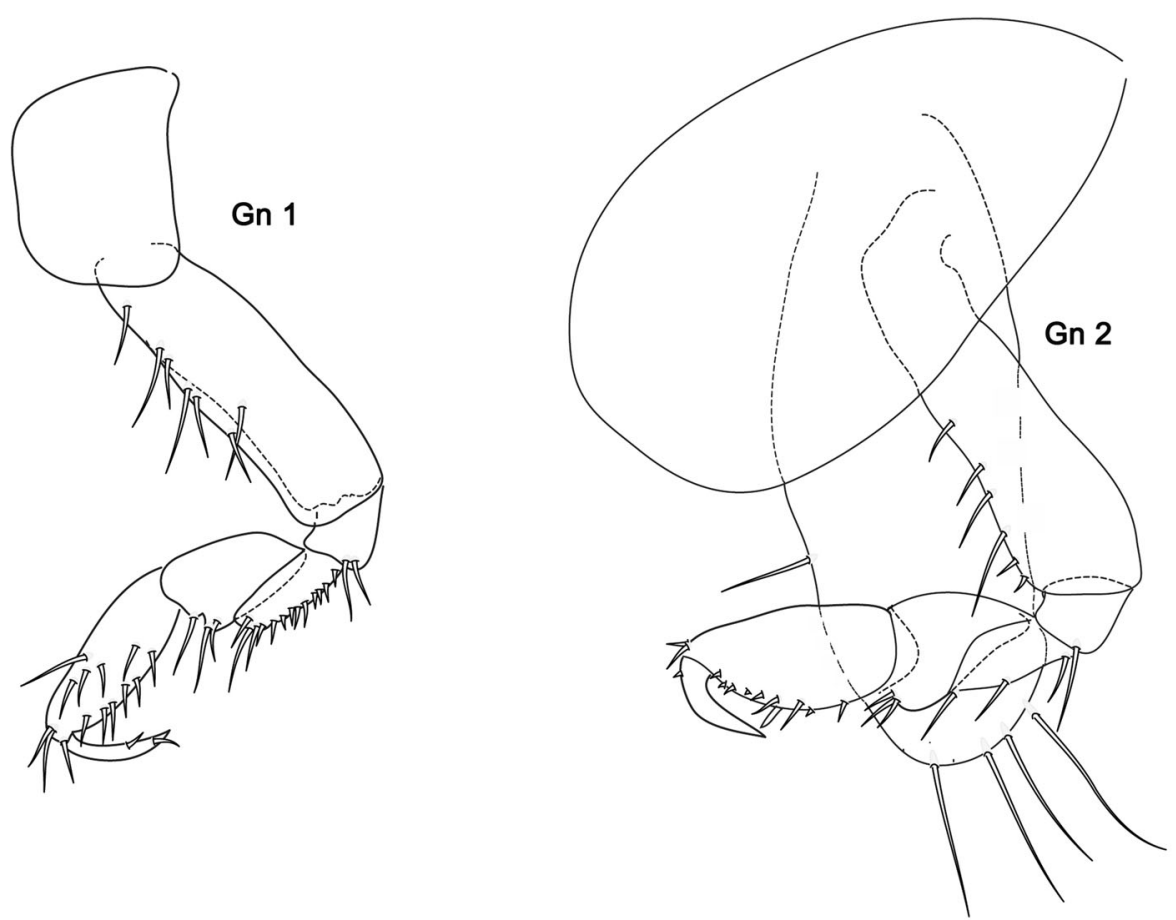

Gn 1 '

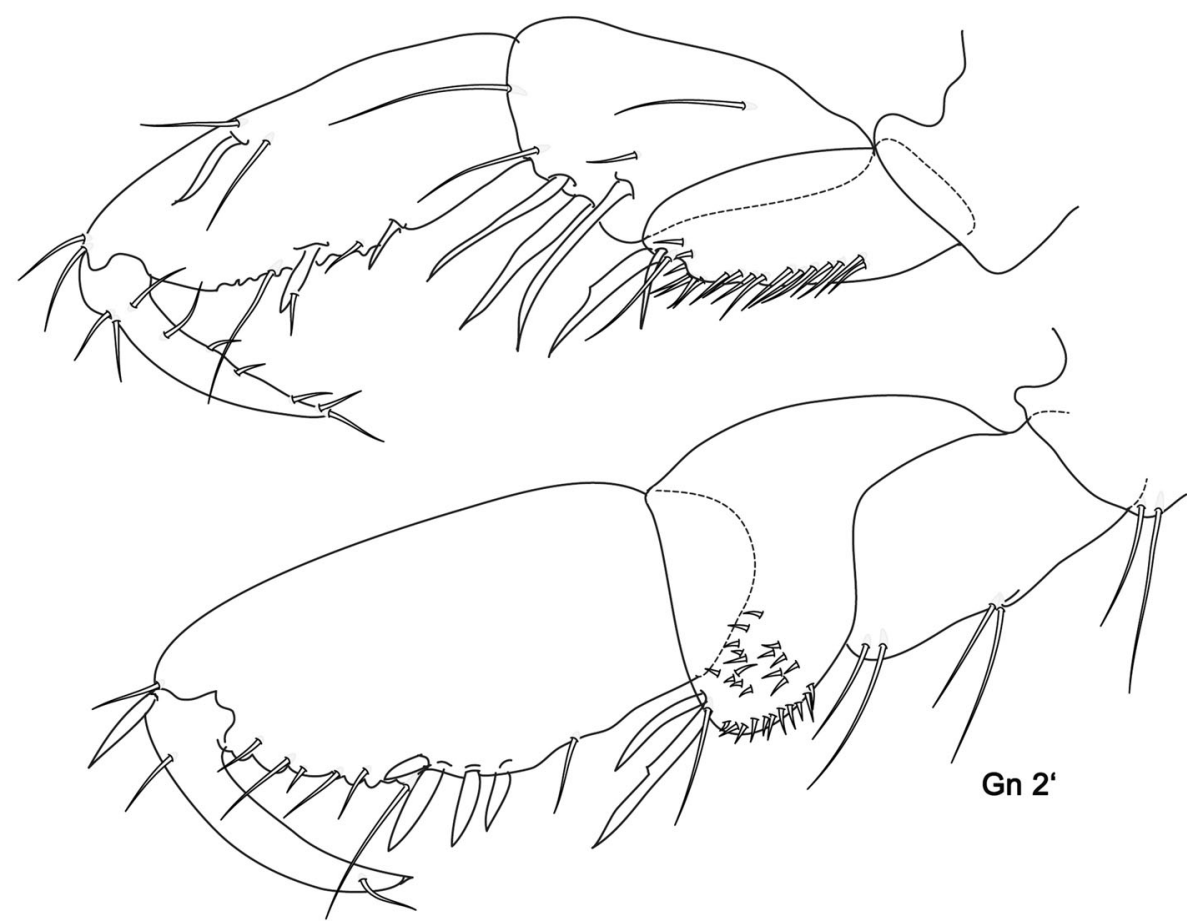

da Cunha, S. macrophthalma Stephensen, 1931 from the bathyal of the N-Atlantic and S. megacheir (Boeck, 1871) from Norway. Except $S$. coutieri all these species show strong sexual dimorphism, while in $S$. coutieri only a single male is known, where Gn 1 propodus shows a clear palmar corner.
Biology of stenothoids associated with sea anemones

Associations between amphipods and sea anemones are probably quite common in nature, but for a long time they were largely overlooked. They were reviewed by Vader (1983); an updated review is in preparation by Vader and 
Fig. 4 Stenothoe boloceropsis n.sp.: P $3-7=$ peraeopods $3-7$; Ep 1-3 = epimeral plates $1-3$; U $1-3=$ uropods $1-3$; $\mathrm{T}=$ telson, $\mathrm{T}^{\prime}$ telson from dorsal

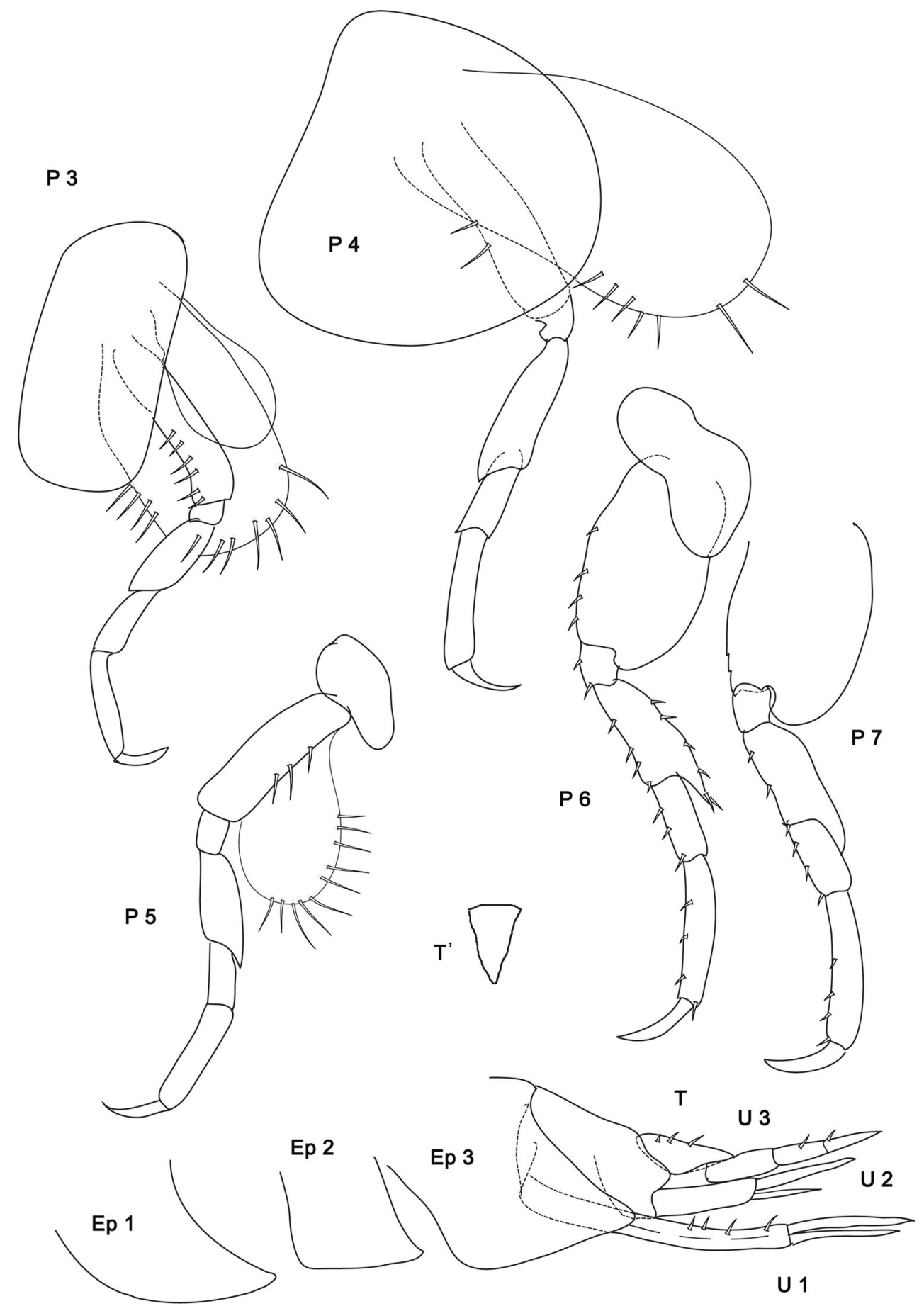

Tandberg. In all known cases, stenothoid associates live on the column and tentacles of the sea anemone host; in recent years, quite a number of these associations have become known. The best studied case is that of Stenothoe brevicornis Sars, 1883, an obligate symbiont of the sea anemone Actinostola callosa (Verrill) in N. Norway and eastern Canada (Vader and Krapp-Schickel 1996, Fenwick and Steele 1983); the species has recently also been found on
Liponema multicornis (Verrill, 1880) in the Gulf of Maine (Auster et al. 2011). The amphipods are found on the outside of the sea anemones (the collecting methods made detailed observations impossible, and the amphipods did not survive well in the laboratory), with usually up to ten specimens per host and a maximum of 44 . In the larger hosts, from 65 to $86 \%$ of the sea anemones harboured amphipods. All size classes of amphipod are represented, 

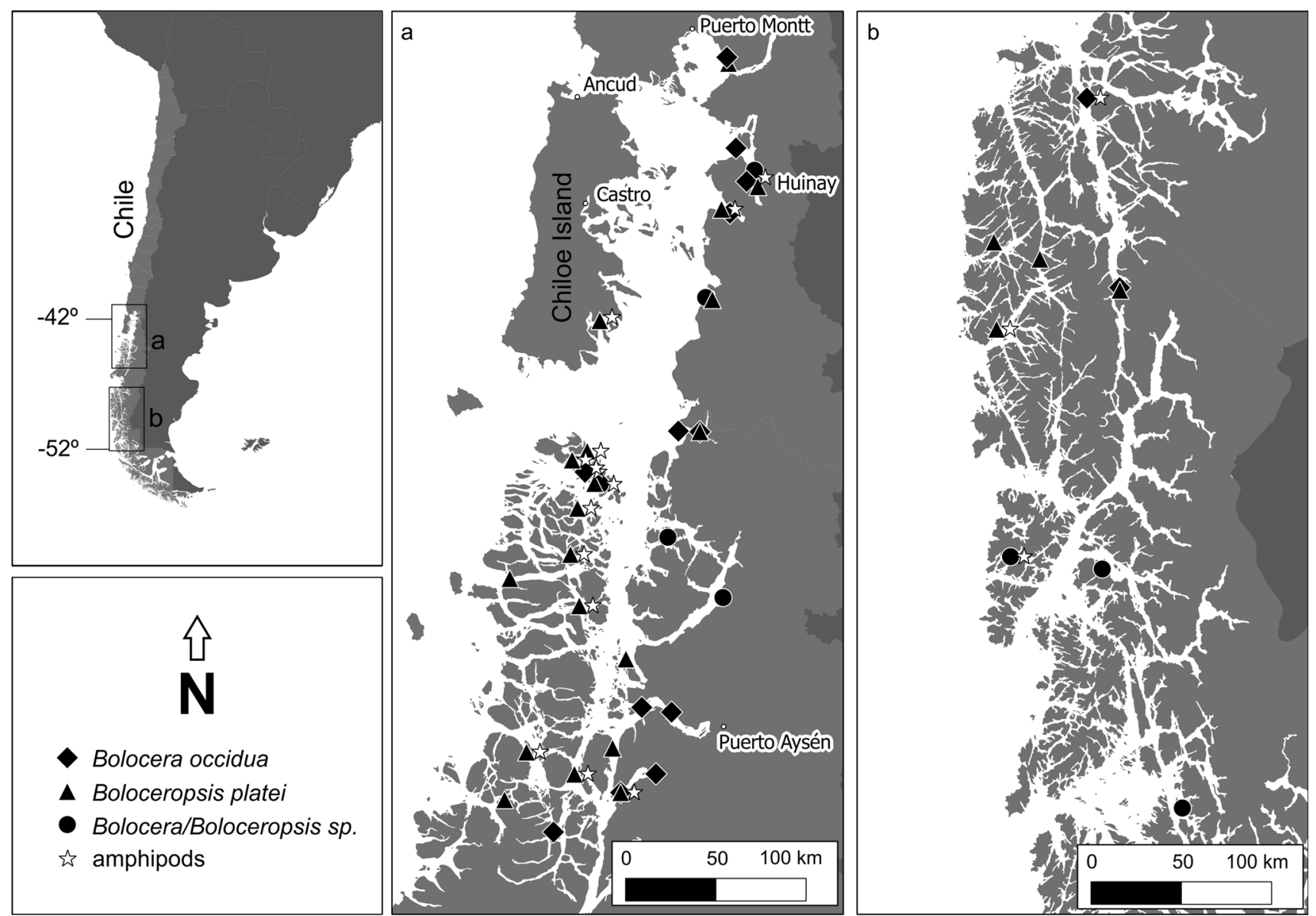

Fig. 5 Distribution map of Boloceropsis platei and Bolocera occidua with and without stenothoid amphipods

also ovigerous females; the species appears to be iteroparous. Surprisingly, a study of stomach contents showed that Stenothoe brevicornis in fact feeds to a considerable amount on host tissue (Moore et al. 1994). No biological data have as yet been collected for $S$. boloceropsis, but it seems to have a way of life quite similar to S. brevicornis.

Natural history of the host, the sea anemone Boloceropsis platei

The actiniid sea anemone Boloceropsis platei can be found in Chilean Patagonia between Lenca, Seno de Reloncavi, Northern Patagonian Zone $\left(41,6720^{\circ} \mathrm{S} ; 72,6561^{\circ} \mathrm{W}\right)$ and Isla Camelo, Central Patagonian Zone $\left(49,19^{\circ} \mathrm{S}\right.$; $75,394^{\circ} \mathrm{W}$ ) between 8 and $40 \mathrm{~m}$ depth (most common between 20 and $30 \mathrm{~m}$ depth). Species identified as Boloceral Boloceropsis sp. were found at 54 of the more than 300 sampling sites; of these, Boloceropsis platei was found at 33 sites. Of the 54 sites, amphipods were observed at 17 sites. Amphipods were most common in the Guaitecas and Chonos Archipielagos (approximately $43-46^{\circ} \mathrm{S}$ ). Specimens of the species Boloceropsis platei are characterized by its white or light pink generally uniform colour (some specimens have a dark ring around the mouth opening), its large size (alive up to $6 \mathrm{~cm}$ pedal disc diameter), the numerous long, non-retractile tentacles (alive up to $13 \mathrm{~cm}$ ) and the small offspring sitting in large groups around many specimens. Specimens of this species live on exposed rock, boulders, gravel or sandy bottom. In the latter case, several small stones have been found attached to the pedal disc. Generally, there are few specimens in an area, but we have also found sites with dozens of specimens at regular distances (between 0.5 and $4 \mathrm{~m}$ ). The specimens are always sitting in an upright position. Little information is available on the biology of this species. A hermit crab with shell ( $\sim 1.5 \mathrm{~cm}$ diameter) has been observed in its gastrocoel. Following Sebens and Paine (1979), embryos can be present in the gastrocoel. This has never been observed in the present study. A small detached specimen was observed making slow rhythmic movements with the tentacles which could be used to move around. When being preserved, specimens rarely throw off tentacles. The very similar species, Bolocera occidua, can be found between Lenca, Seno de Reloncavi, Northern Patagonian Zone 
$\left(41,6720333333^{\circ} \mathrm{S} ; 72,6561^{\circ} \mathrm{W}\right)$ and Angostura Inglesa, Canal

Messier, Central Patagonian Zone $\left(48,9747222222^{\circ} \mathrm{S}\right.$; $74,4213611111^{\circ} \mathrm{W}$ ), from $25 \mathrm{~m}$ down to $233 \mathrm{~m}$ (Häussermann 2006). It was found at 20 of the more than 300 sampling sites. Its colour varies between white, pink and dark brown. Its tentacles are also non-retractile, but thrown off readily when disturbed. The relationship between body size and tentacle length also differs, and in adult animals, the body of $B$. occidua is smaller in relationship to its tentacles (however, with subadult specimens, this is different). The morphology and histology (including cnidae) of the two species are so similar that no character for clear distinction has been found yet. The phenotypes can generally be distinguished in situ (especially the dark brown one).

Acknowledgments This is publication nr. 119 of Huinay Scientific Field Station. Funding for VH was partially provided through Fondecyt project nr 1131039 and through a PEW marine fellowship. Many thanks also to NAVIMAG, Naviera Austral, Transmarchilay, DAP, CAP, Añihue Reserve, the Pumalin Foundation and the crew of the Saoirse for their support.

\section{References}

Auster PJ, Heinonen KB, Watling L, Parrish-Kuhn C, Heupel E, Lindholm J (2011) A rare deepwater anemone and its associates in the Stellwagen Bank National Marine Sanctuary (Gulf of Maine, north-west Atlantic). Mar Biodivers Rec 4(19):4

Barnard JL (1962) Benthic marine amphipods of southern California. Families Amphilochidae, Leucothoidae. Stenothoidae, Argissidae, Hyalidae. Pac Nat 3:116-163

Barnard JL (1970) Sublittoral Gammaridea (Amphipoda) of the Hawaiian Islands. Smiths Contr Zool 34:1-286

Bellan-Santini D (2005) Stenothoidae (Crustacea: Amphipoda) of hydrothermal vents and surroundings on the Mid-Atlantic Ridge, Azores Triple Junction Zone. J Nat Hist 39:3435-3452

Boeck A (1871) Crustacea Amphipoda Borealia et Arctica. Forh Vidensk Selsk Christiania 1870:83-280

Chevreux E (1935) Amphipodes provénant des campagnes du Prince Albert I de Monaco. Rés Camp Sci Prince Albert I 90:41-152

Fenwick GD, Steele DH (1983) Amphipods of Placentia Bay, Newfoundland. Mem Univ Newfoundland. Occas Pap Biol $7: 1-22$

Häussermann V (2006) Biodiversity of Chilean sea anemones (Cnidaria: Anthozoa): distribution patterns and biogeographic implications; including new records for the fjord region. Investig Mar 34(2):23-35

HäussermannV, Försterra G (eds) (2009) Marine benthic fauna of Chilean Patagonia. Nature in Focus, Puerto Montt, p 1000

Krapp-Schickel G (1976) Die Gattung Stenothoe (Crustacea, Amphipoda) im Mittelmeer. Bijdr Dierk 46:1-15
Krapp-Schickel T (2009) New and poorly described stenothoids (Crustacea, Amphipoda) from the Pacific Ocean. Mem Mus Vic 66:95-116

Krapp-Schickel T (2011) New Antarctic stenothoids sensu lato (Amphipoda, Crustacea). Eur J Taxon 2:1-17. doi:10.5852/ejt. 2011.2

Krapp-Schickel T, Vader W (2009) A new Parametopella species (Crustacea: Amphipoda: Stenothoidae) from Antholoba achates (Anthozoa: Actiniaria) from Coquimbo, Chile (with remarks on Parametopa alaskensis (Holmes)). J Mar Biol Assoc UK 89(6):1281-1289

Mc Murrich JP (1904) The Actiniae of the plate collection. Zool Jb Suppl 6(25):215-307

McMurrich JP (1893) Scientific results of explorations by the U. S. Fish Commission Steamer Albatross. No. XXIII. Report on the Actiniae collected by the United States Fish Commission Steamer Albatross during the winter of 1887-1888. Proc US Nat Mus. 16: 119-216

Moore PG, Rainbow PS, Vader W (1994) On the feeding and comparative biology of iron in coelenterate-associated gammaridean amphipods (Crustacea) from N. Norway. J Exp Mar Biol Ecol 178:205-231

Myers AA (1985) Shallow-water, coral reef and mangrove Amphipoda (Gammaridea) of Fiji. Rec Aust Mus Suppl 5:1-144

Ren X (1992) Studies on the Gammaridea (Crustacea: Amphipoda) from Jiaozhou bay (Yellow Sea). Trans Chin Crustac Soc 3:214-317 (In Chinese)

Sars GO (1883) Oversigt over Norges Crustaceer med foreløbige Bemærkninger over de nye eller mindre bekjendte Arte. I. (Podophthalmata-Cumacea-Isopoda-Amphipoda). Forh VidenskSelsk Christiania 18(1):1-24

Sebens KP, Paine RT (1979) Biogeography of anthozoans along the west coast of South America: habitat, disturbance, and prey availability. In: Proceedings of the international symposium on marine biogeography and evolution in the southern hemisphere, vol 1. New Zealand Department of Scientific and Industrial Research Information Series 137. Auckland, pp 219-238

Stephensen K (1931) Crustacea Malacostraca. VII. (Amphipoda III.) Danish Ingolf-Expedition 3:179-290

Stephensen K (1949) The Amphipoda of Tristan da Cunha. Res Nor Sci Exped Tristan da Cunha 1937-1938(19):1-61

Vader W (1983) Associations between amphipods (Crustacea: Amphipoda) and sea anemones (Anthozoa, Actiniaria). Mem Aust Mus 18:141-153

Vader W, Krapp-Schickel G (1996) Redescription and biology of Stenothoe brevicornis Sars (Amphipoda: Crustacea), an obligate associate of the sea anemone Actinostola callosa (Verrill). J Nat Hist 30:51-66

Verrill AE (1880) Notice of recent additions to the marine Invertebra of the Northeastern coast of America, with descriptions of new genera and species and critical remarks on others. Part II. Mollusca, with notes on Annelida, Echnodermata, etc., collected by the United States Fish Commission. Proc US Nat Mus 3:356-409

Verrill AE (1882) Notice of a remarkable marine fauna occupying the outer banks off the southern coast of New England, no.7. Am J Sci 24(40):360-371 ser3 